\title{
PENGEMBANGAN PERANGKAT PEMBELAJARAN HIMPUNAN DENGAN PENDEKATAN REALISTIK BERORIENTASI PENDIDIKAN KARAKTER DALAM MENINGKATKAN HASIL BELAJAR SISWA
}

\section{SOME LEARNING DEVICES FOR SET TOPIC WITH REALISTIC APPROACHES ORIENTED TO CHARACTER EDUCATION IN IMPROVING STUDENT LEARNING OUTCOMES}

\author{
Riza Aldira $^{a}$, I Nengah Supartab ${ }^{b}$ I Gusti Putu Sudiarta ${ }^{c}$ \\ Pendidikan Matematika, Universitas Pendidikan Ganesha \\ J1. Udayana No. 11 Singaraja \\ arizaaldira0@gmail.com, ${ }^{\mathrm{b}}$ nengah.suparta@undiksha.ac.id, ${ }^{\mathrm{c}}$ gussudiarta@undiksha.ac.id
}

\begin{abstract}
ABSTRAK
Penelitian ini bertujuan untuk mendeskripsikan karakteristik dan mengetahui kualitas perangkat pembelajaran himpunan dengan pendekatan Matematika Realistik berorientasi pendidikan karakter pada siswa jenjang SMP. Penelitian ini merupakan penelitian pengembangan dengan model pengembangan yang mengacu pada model Plomp (Plomp, 2013) yang terdiri dari tiga fase, yaitu fase penelitian pendahuluan (preliminary research), fase pembuatan prototype (prototyping phase), fase penilaian (assessment phase). Penelitian dilakukan di Sekolah Menengah Pertama (SMP) Muhammadiyah 1 Denpasar dengan populasi 191 siswa dari lima kelas yang ada Perangkat pembelajaran yang dikembangkan adalah Buku Petunjuk Guru dan Buku Siswa. Perangkat ini dimaksudkan untuk mendukung implementasi pendekatan matematika realistik dalam meningkatkan hasil belajar. Untuk menjamin kualitas perangkat yag dihasilkan, kita lakukan uji / test utnuk aspek kevalidan, kepraktisan dan keefektifan. Berdasarkan analisis data dapat kita simpulkan, perangkat yang dihasikan memiliki kualitas berikut: 1) buku siswa valid dengan rata - rata nilai 3,175 maka dari itu dapat dinyatakan valid dan buku guru valid dengan rata - rata nilai 3,128 dinyatakan valid. 2) angket respon siswa terhadap buku siswa, angket respon guru terhadap buku guru, dan pengamatan keterlaksanaan pembelajaran dapat dinyatakan praktis. 3) Tes hasil belajar siswa dan instrumen sikap kerja keras tergolong dalam kategori sangat baik.
\end{abstract}

Kata kunci : Pendidikan Karakter, Pendekatan Matematika Realistik, Hasil Belajar Siswa, Media Pembelajaran

\begin{abstract}
This study aims to describe the characteristics and to know the quality of learning media for set topic using realistic mathematics approach based on character building in junior high school students. This research is developmental research using Plomp model development (Plomp, 2013) which consists of three phases: preliminary research phase, prototyping phase, and assessment phase. This study was conducted at Junior High School (SMP) of Muhammadiyah 1 Denpasar. The subject in this research are 191 students from five existing classes. We developed teacher's book and student's book. These media are intended for supporting the implementation of realistic mathematics approaches to improve students learning outcomes. To guarantee the quality of media, we did tests for validity, practicality, and effectiveness aspects. Based on data analysis we may conclude that, students book and teachers book are: 1) valid, based on average scores of 3.175 and 3.128 , respectively this means
\end{abstract}


that they are valid. 2) practically, based on questionnaire respons from students and teachers toward observation of learning implementation. 3) effective, based on students' test and teachers' assessment.

Keywords : Character Education, Realistic Mathematics Approach, Student Learning Outcomes, Learning Media

\section{Pendahuluan}

Pembahasan tentang sifat konsep himpunan telah dilakukan selama lebih dari dua ribu tahun dan perdebatan belum berakhir menurut Matos (1990) dalam B, Z, D, Dolk, \& Eerde (2013). Konsep himpunan merupakan salah satu materi sekolah yang banyak menimbulkan kesulitan pada siswa (Syaiful Bahri Djamarah, 2003). Pada materi himpunan, banyak siswa kurang memahami sifat-sifat himpunan. Menurut Ahmadi (2008) siswa sulit untuk mengaitkan himpunan dengan sifat-sifat yang ada dan siswa juga hanya menghafal sifatsifat himpunan yang terbentuk. Akibatnya, jika diberikan soal-soal yang bentuknya lebih variatif siswa tidak mampu untuk menyelesaikannya (Ahmadi,2008). Materi himpunan sampai saat ini masih menjadi materi yang sulit untuk dipelajari siswa. Retno Dewi Tanjungsari (2011) menemukan kesulitan siswa dalam mempelajari materi tersebut yang berupa (1) kesulitan dalam kemampuan menerjemahkan (linguistic knowledge) ditunjukkan dengan kesalahan dalam menafsirkan bahasa soal (2) kesulitan dalam menggunakan konsep termasuk didalamnya ketidakmampuan untuk mengingat konsep, ketidakmampuan mendeduksi informasi berguna dari suatu konsep dan kurangnya kemampuan memahami (schematic knowledge) yang ditunjukkan dengan kurang lengkap dalam menuliskan rumus, dan (3) kesulitan dalam kemampuan algoritma termasuk didalamnya kurangnya kemampuan perencanaan (strategy knowledge) dan dalam kemampuan penyelesaian (algorithmic knowledge) ditunjukkan dengan tidak mengerjakan soal, kurang langkah, belum selesai, kurangnya ketelitian siswa dalam mengerjakan.

Untuk mengatasi permasalahan tersebut di atas, dianggap perlu menggunakan suatu pendekatan pembelajaran yang menyebabkan siswa ikut berpartisipasi aktif dalam kegiatan pembelajaran di kelas (Dwiyana, 2015). Pendekatan matematika realistik, menurut Freudental dalam Ahmad Susanto (2013) menyatakan bahwa matematika harus dikaitkan dengan realita dan matematika merupakan suatu aktivitas manusia. Pada Pendekatan Realistik Matematika (PMR) disini siswa diberi kesempatan untuk mengaplikasikan konsepkonsep matematika untuk memecahkan masalah sehari-hari atau masalah dalam bidang lainnya dikarenakan selama ini pendekatan yang digunakan cenderung pada pemberian 
informasi dan matematika digunakan sebagai alat bantu (Dwiyana, 2015).

Namun guru juga sebaiknya tidak hanya mengutamakan pengetahuan atau hasil belajar siswa saja, melainkan guru juga harus dapat menanamkan karakter yang baik pada siswa (Haryati, 2017). Dengan menggunakan PMR guru akan membuat siswa lebih berpartisipasi aktif dan semangat dalam pembelajaran (Dwiyana, 2015). Apabila siswa sudah dapat memunculkan semangat dalam dirinya tentang pelajaran matematika maka selanjutya munculah rasa ingin tahu pada diri siswa tersebut untuk lebih mendalami pelajaran matematika. Dari rasa ingin tahu kemudian guru mencoba untuk memberikan permasalahan kepada siswa sehingga membuat siswa - siswa bekerja keras dalam menyelesaikan permasalahan tersebut.

Salah satu materi yang paling banyak kendalanya adalah materi himpunan, karena materi ini dari tahun ke tahun dilakukan dengan menggunakan media buku saja sehingga bisa dikatakan tanpa variasi dalam pembelajaran (Ahmadi, 2008). Hal ini diduga kuat juga menjadi salah satu penyebab rendahnya hasil belajar matematika siswa (Sugiati Tabrang, 2016).

Berdasarkan uraian di atas, perencanaan pembelajaran yang dituangkan dalam perangkat pembelajaran berupa Buku Petunjuk Guru dan Buku Siswa sangat penting untuk dibuat. Maka dari itu peneliti dan guru sepakat melakukan suatu tindakan untuk mengatasi permasalahan tersebut dengan melakukan pengembangan perangkat pembelajaran himpunandengan pendekatan realistik berorientasi pendidikan karakter untuk meningkatkan hasil belajar siswa.

\section{Metode Penelitian}

Jenis penelitian ini adalah pengembangan yang mengacu pada model Plomp (Plomp,2013) yang terdiri dari tiga fase, yaitu fase penelitian pendahuluan (preliminary research), fase pembuatan prototype (prototyping phase), fase penilaian (assessment phase).

(1) Fase Penelitian Pendahuluan (Preliminary Research) adalah meninjau proses pembelajaran yang dilaksanakan di kelas, melakukan wawancara dengan guru matematika kelas VII mengenai kendala - kendala siswa dalam pembelajaran matematika. 
Tabel 1. Fase Penelitian Pendahuluan (Preliminary Research)

\begin{tabular}{|c|c|}
\hline Kendala guru & $\begin{array}{c}\text { Pengamatan } \\
\text { peneliti }\end{array}$ \\
\hline $\begin{array}{c}\text { Berdasarkan wawancara } \\
\text { dengan guru matematika } \\
\text { di SMP Muhammadiyah } 1 \\
\text { Denpasar, pembelajaran } \\
\text { yang dilakukan selama ini } \\
\text { masih kurang maksimal, } \\
\text { khususnya pada mata } \\
\text { pelajaran Himpunan. Pada } \\
\text { umumnya guru } \\
\text { memberikan buku paket } \\
\text { siswa dan lembar kerja } \\
\text { siswa yang memuat } \\
\text { tampilan rumus siap pakai } \\
\text { disertai dengan beberapa } \\
\text { contoh soal yang sifatnya } \\
\text { masih abstrak (kurang } \\
\text { terkait dengan kehidupan } \\
\text { sehari-hari) dan } \\
\text { selanjutnya diisi dengan } \\
\text { latihan-latihan soal. }\end{array}$ & $\begin{array}{c}\text { Pembelajaran yang } \\
\text { selama ini dilakukan } \\
\text { guru masih kurang } \\
\text { maksimal dalam } \\
\text { melibatkan siswa. Di } \\
\text { sini tampak masih } \\
\text { banyak siswa yang } \\
\text { terlihat pasif dalam } \\
\text { merespons pertanyaan- } \\
\text { pertanyaan yang } \\
\text { diberikan oleh guru. } \\
\text { Pada proses } \\
\text { pembelajaran guru } \\
\text { masih memberikan } \\
\text { contoh soal serta } \\
\text { alternatif } \\
\text { penyelesaiannya, dan } \\
\text { memberikan soal } \\
\text { latihan yang } \\
\text { dikerjakan secara } \\
\text { kelompok. }\end{array}$ \\
\hline
\end{tabular}

Fase Pembuatan Prototype

(Prototyping Phase) adalah menguji validitas perangkat pembelajaran yang masih berupa prototipe I oleh 2 orang pakar (validator) dari Universitas Pendidikan Ganesha. Adapun Adapun proses dalam fase ini yaitu proses iterasi analisis, proses desain dan pengembangan, serta proses evaluasi dan revisi. Semua proses ini menjadi satu kesatuan dalam proses desain dan pengembangan produk, proses validasi dan revisi produk, proses uji coba produk dan revisi. Tahap iterasi analisis terus berkelanjutan, sebagai dasar proses revisi produk. Produk yang dimaksudkan di sini meliputi dua komponen, yaitu buku siswa dan buku petunjuk guru.

Fase Penilaian (Assessment Phase).

Penelitian ini bertujuan untuk mendeskripsikan karakteristik dan mengetahui kualitas perangkat pembelajaran himpunan dengan pendekatan Matematika Realistik berorientasi pendidikan karakter pada siswa di SMP Muhammadiyah 1 Denpasar.

Peserta

Penelitian ini dilaksanakan sampai mendapatkan produk final yang melibatkan dua orang validator, dua orang guru matematika di SMP Muhammadiyah 1 Denpasar, 38 orang siswa dari kelas VIIA, 39 orang siswa dari kelas VIIB, 37 orang siswa dari kelas VIIC, 38 orang siswa dari kelas VIID, dan 39 orang siswa dari kelas VIIE sehingga diperoleh perangkat pembelajaran himpunan yang berkualitas valid, praktis dan efektif.

Uji coba terbatas dilaksanakan pada kelas VII E, kelas ini dipilih secara random dan jumlah siswa yang diambil sebagai subjek penelitian sebanyak 39 orang dimana siswa tersebut mempunyai kemampuan yang heterogen. Selanjutnya dilakukan uji coba lapangan 1 yang dilaksanakan di kelas VII A dan VII B, kelas ini dipilih secara random dengan jumlah siswa 77 orang. Setelah melakukan uji coba lapangan 1 lalu dilakukan uji coba lapangan 2. Uji coba ini 
dilaksanakan pada kelas VII C, dan VII D kelas ini dipilih secara random dengan jumlah siswa 75 orang.

\section{Hasil dan Pembahasan}

Berdasarkan pengujian produk terhadap uji validitas, kepraktisan dan keefektifan bahan ajar diperoleh hasil sebagai berikut:

\section{Aspek Validitas}

\section{a. Validitas Instrumen Penelitian}

Instrument yang digunakan dalam penelitian ini meliputi 4 aspek, yaitu lembar validasi buku siswa, lembar validasi buku petunjuk guru, lembar validasi angket respons siswa, lembar validasi angket respons guru.

Tabel 2. Rangkuman Hasil Validasi Instrumen Penelitian

\begin{tabular}{lccc}
\hline No. & Instrumen Penelitian & \multicolumn{2}{c}{ Hasil Validasi } \\
\cline { 3 - 4 } & & Validator & Validator II \\
& & I & \\
\hline 1. & Lembar Validasi & Layak pakai & Layak pakai \\
& Buku Siswa & dengan revisi & dengan revisi \\
\hline 2. & Lembar Validasi & Layak pakai & Layak pakai \\
& Buku Guru & dengan revisi & dengan revisi \\
\hline 3. & Lembar Validasi & Layak pakai & Layak pakai \\
& Angket Respons & dengan revisi & dengan revisi \\
& Siswa & & \\
\hline 4. & Lembar Validasi & Layak pakai & Layak pakai \\
& Angket Respons & dengan revisi & dengan revisi \\
& Guru & & \\
\hline
\end{tabular}

\section{b. Validitas Buku}

Tabel 3. Hasil Validasi Buku Siswa

\begin{tabular}{|c|c|c|c|c|c|}
\hline \multirow[t]{2}{*}{ No } & \multirow{2}{*}{$\begin{array}{c}\text { Aspek } \\
\text { yang } \\
\text { dinilai }\end{array}$} & \multicolumn{2}{|c|}{$\begin{array}{c}\text { Rata-rata skor } \\
\text { validator }\end{array}$} & \multirow[t]{2}{*}{ Jumlah } & \multirow[t]{2}{*}{$\begin{array}{l}\text { Rata- } \\
\text { rata }\end{array}$} \\
\hline & & I & II & & \\
\hline 1 & $\begin{array}{c}\text { Isi } \\
\text { Buku } \\
\text { Siswa }\end{array}$ & 2,67 & 3,375 & 6,045 & 3,02 \\
\hline 2 & $\begin{array}{c}\text { Cara } \\
\text { Penyaji } \\
\text { an }\end{array}$ & 2,67 & 3,67 & 6,34 & 3,17 \\
\hline 3 & $\begin{array}{l}\text { Bentuk } \\
\text { Fisik }\end{array}$ & 2,67 & 4 & 6,67 & 3,335 \\
\hline \multicolumn{5}{|c|}{ Jumlah } & 9,525 \\
\hline & Rat & ata. & lah $(S$ & & 3,175 \\
\hline
\end{tabular}

Berdasarkan tabel di atas dapat dilihat skor rata-rata hasil validasi buku siswa adalah 3,175 sehingga dapat dinyatakan bahwa buku siswa dapat dinyatakan valid karena nilai Sr berada pada rentang $2,5 \leq S r<3,5$. Sehingga buku siswa ini dapat digunakan dengan beberpa revisi berdasarkan saran dari para validator.

Tabel 4. Hasil Validasi Buku Petunjuk Guru

\begin{tabular}{|c|c|c|c|c|c|}
\hline \multirow[t]{2}{*}{ No. } & \multirow{2}{*}{$\begin{array}{c}\text { Aspek } \\
\text { yang } \\
\text { dinilai }\end{array}$} & \multicolumn{2}{|c|}{$\begin{array}{l}\text { Rata-rata skor } \\
\text { validator }\end{array}$} & \multirow[t]{2}{*}{ Jumlah } & \multirow[t]{2}{*}{$\begin{array}{l}\text { Rata } \\
\text {-rata }\end{array}$} \\
\hline & & I & II & & \\
\hline 1 & $\begin{array}{l}\text { Isi Buku } \\
\text { Siswa }\end{array}$ & 2,6 & 3,5 & 6,1 & 3,05 \\
\hline 2 & $\begin{array}{c}\text { Cara } \\
\text { Penyajian }\end{array}$ & 2,5 & 3,5 & 6 & 3 \\
\hline 3 & $\begin{array}{l}\text { Bentuk } \\
\text { Fisik }\end{array}$ & 2,67 & 4 & 6,67 & 3,335 \\
\hline \multicolumn{5}{|c|}{ Jumlah } & 9,385 \\
\hline & Rat & ata iv & ah (Sr) & & 3,128 \\
\hline
\end{tabular}


Berdasarkan tabel di atas dapat dilihat skor rata-rata hasil validasi buku petunjuk guru adalah 3,128, sehingga dapat dinyatakan bahwa buku petunjuk guru dapat dinyatakan valid karena nilai Sr berada pada rentang $2,5 \leq S r<3,5$. Sehingga buku petunjuk guru ini dapat digunakan dengan beberpa revisi berdasarkan saran dari para validator.

\section{Aspek Kepraktisan}

\section{a. Angket Respons Siswa}

Tabel 5. Rangkuman Analisis Angket Respons Siswa Pada Uji Coba II

\begin{tabular}{lllcc}
\hline No & Rata-rata skor & Kategori & $\begin{array}{c}\text { Banyak } \\
\text { siswa }\end{array}$ & Persentase \\
\hline 1. & Skor $\geq 3,50$ & $\begin{array}{l}\text { Sangat } \\
\text { praktis }\end{array}$ & 5 & $6,67 \%$ \\
\hline 2. & $3,00 \leq$ Skor $<3,50$ & Praktis & 70 & $93,3 \%$ \\
\hline
\end{tabular}

Berdasarkan skor tersebut, dapat disimpulkan bahwa hasil pengembangan buku siswa sudah memenuhi aspek kepraktisan.

\section{b. Angket Respons Guru}

Hasil analisis angket respons guru mengenai buku petunjuk guru menunjukkan bahwa hasil pengembangan termasuk dalam kategori "praktis". Hal ini dapat dilihat dari rata-rata skor angket respons guru terhadap buku petunjuk guru pada uji coba lapangan 2 sebesar 3,27 dimana nilai ini terletak pada interval $2,5 \leq S R<3,5$.

\section{c. Analisis Hasil Pengamatan}

Keterlaksanaan Pembelajaran

Tabel 6. Rangkuman Hasil Pengamatan

Keterlaksanaan

\begin{tabular}{ccccc}
\hline No. & Pengamat & $\begin{array}{c}\text { Rata-rata } \\
\text { hasil } \\
\text { pengamatan }\end{array}$ & $\begin{array}{c}\text { Skor Pengamat } \\
\text { (hasil/banyak item) }\end{array}$ & $\begin{array}{c}\text { Rata- } \\
\text { rata }\end{array}$ \\
\cline { 1 - 4 } $\mathbf{1 .}$ & I & 5,81 & 2,90 & \multirow{2}{\mathbf{298}}{} \\
\hline $\mathbf{2 .}$ & II & 6,125 & 3,06 & \\
\hline
\end{tabular}

Berdasarkan rangkuman data pada tabel di atas, dapat disimpulkan bahwa keterlaksanaan penggunaan buku sudah dalam kategori "praktis" karena skor akhir yang diperoleh sebesar 2,98 terletak pada interval $2,5 \leq S R<3,5$.

Jadi, dapat disimpulkan bahwa penerapan hasil pengembangan pada uji coba lapangan II sudah terlaksana dengan baik.

\section{Aspek Keefektifan}

\section{a. Hasil Belajar Matematika Siswa}

Salah satu kesalahpahaman dalam mengoperasikan himpunan adalah

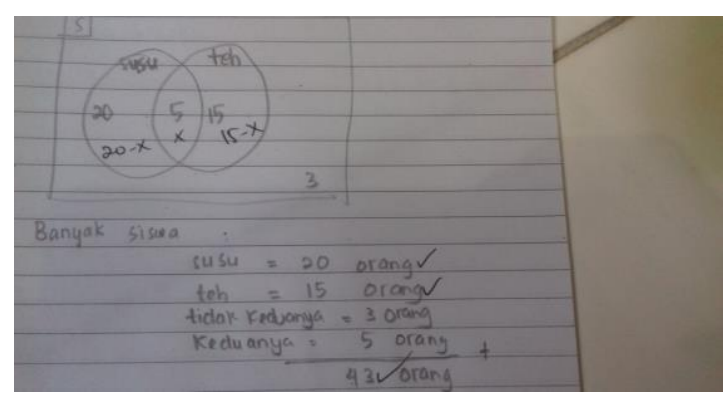

Gambar 1. Hasil Belajar Siswa

Saat mengerjakan soal himpunan seperti di atas, kebanyakan siswa yang langsung menjumlahkan angka - angka yang terlihat pada soal. Seharusnya siswa dapat lebih 
fokus saat membaca apa yang ditanyakan guru.

Tabel 7. Rangkuman Tes Hasil Belajar Matematika

\begin{tabular}{cccc}
\hline Hasil Tes & $\begin{array}{c}\text { Jumlah } \\
\text { Nilai } \\
\text { Total }\end{array}$ & $\begin{array}{c}\text { Rata-rata } \\
\text { Nilai } \\
\text { Total }\end{array}$ & Kriteria \\
\hline $\begin{array}{c}\text { Uji Coba } \\
\text { Lapangan 1 }\end{array}$ & 6256 & 81,24 & $\begin{array}{c}\text { Sangat } \\
\text { Baik }\end{array}$ \\
\hline $\begin{array}{c}\text { Uji Coba } \\
\text { Lapangan 2 }\end{array}$ & 9888 & 83,04 & $\begin{array}{c}\text { Sangat } \\
\text { Baik }\end{array}$ \\
\hline
\end{tabular}

Karena rata-rata nilai siswa adalah sebesar 81,24 pada uji coba lapangan I dan 83,04 pada uji coba lapangan II maka efektivitas produk tergolong dalam kategori "sangat baik" karena nilai ini terletak pada interval $H \geq 75$.

\section{b. Hasil Angket Sikap Kerja Keras Selama Kegiatan Pembelajaran}

Perangkat pembelajaran yang dikembangkan dalam penelitian ini selain berfokus pada hasil belajar siswa juga berorientasi pada perkembangan karakter siswa yaitu terkait sikap kerja keras.

Penilaian karakter siswa tersebut diperoleh melalui rata-rata skor dari angket penilaian diri, angket penilaian antar teman serta lembar observasi penilaian sikap oleh pengamat.
Tabel 8. Rangkuman Hasil Penilaian Sikap Kerja Keras

\begin{tabular}{|c|c|c|c|}
\hline Uji Coba & Teknik Penilaian & & Kriteria \\
\hline \multirow{3}{*}{$\begin{array}{l}\text { Uji Coba } \\
\text { Lapangan } \\
\mathbf{1}\end{array}$} & Penilaian Diri & & \multirow[t]{3}{*}{ Baik } \\
\hline & $\begin{array}{l}\text { Penilaian } \\
\text { Teman }\end{array}$ & Antar & \\
\hline & Pengamatan & & \\
\hline \multirow{3}{*}{$\begin{array}{l}\text { Uji Coba } \\
\text { Lapangan } \\
2\end{array}$} & Penilaian Diri & & \multirow[t]{3}{*}{ Baik } \\
\hline & $\begin{array}{l}\text { Penilaian } \\
\text { Teman }\end{array}$ & Antar & \\
\hline & Pengamatan & & \\
\hline
\end{tabular}

Berdasarkan Tabel di atas diketahui bahwa skor akhir dari angket sikap kerja keras pada uji coba lapangan I adalah sebesar 2,94. Sedangkan pada uji coba lapangan II diperoleh skor akhir dari angket sikap kerja keras adalah 2,99. Angka-angka tersebut menunjukkan bahwa hasil penilaian sikap kerja keras yang ditunjukkan peserta didik tergolong dalam kategori "Baik" karena nilai ini terletak pada interval $2,33<$ skor $\leq 3,33$.

\section{Kesimpulan}

Penelitian ini dilatar belakangi oleh rendahnya hasil belajar pembelajaran himpunan yang selama ini sudah diterapkan. Hal ini disebabkan kurangnya perangkat pembelajaran yang dapat membantu siswa dalam memahami konsep matematika yang lebih sistematis dalam proses pembelajarannya. Penelitian ini bertujuan untuk mengembangkan perangkat pembelajaran himpunan yang lebih 
sistematis dan lebih menarik bagi siswa yaitu berupa Buku Siswa dan Buku Petunjuk Guru. Pengembangan perangkat pembelajaran didasarkan pada pendekatan realistik yang berorientasi pendidikan karakter yang sudah terbukti mampu meningkatkan hasil belajar matematika siswa melalui beberapa penelitian yang sudah ada. Dasar teori pengembangan yang digunakan adalah model pengembangan dari Plomp (2013), yaitu melalui fase preliminary research (investigasi awal), fase prototyping (iterasi analisis, desain, pengembangan, evaluasi formatif, dan revisi), serta fase assessment (penilaian semi sumatif).

Dari ketiga langkah tersebut, dihasilkanlah perangkat pembelajaran himpunan (Buku Siswa dan Buku Petunjuk Guru) yang valid, praktis, dan efektif. Hal ini dapat dilihat dari hasil validasi kedua validator, hasil analisis respons guru dan siswa, hasil analisis lembar pengamatan keterlaksanaan, dan hasil tes kemampuan pemahaman konsep matematika siswa.

\section{Pengembangan... (Riza)}

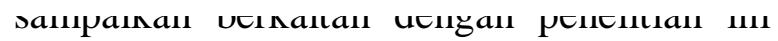
adalah (1) Materi pembelajaran yang dikembangkan dalam penelitian ini hanya sebatas materi himpunan SMP kelas VII (2) Pembelajaran yang digunakan dalam penelitian ini hanya terbatas pada pembelajaran dengan pendekatan realistik berorientasi pendidikan karakter (3) Pembelajaran Matematika di SMP diharapkan dapat menggunakan pembelajaran dengan pendekatan realistik berorientasi pendidikan karakter karena masalah matematika dapat dikemas dekat dengan kehidupan sehari-hari.

\section{Ucapan Terimakasih}

Kami berterima kasih kepada seluruh siswa dan guru mapel yang berpartisipasi dalam penelitian ini. Kami juga mengucapkan terima kasih kepada Dekan Fakultas Pendidikan Matematika Undiksha berserta jajarannya yang mendukung penelitian ini.

\section{Pustaka}

Ahmad Susanto, 2013. Teori Belajar Dan Pembelajaran di Sekolah Dasar. Kencana.

Ahmadi, A., 2008. Psikologi Pendidikan. Jakarta: PT. Rineka Cipta

A.R, Aisyah. 2014. The Implementation Of Character Education Through Contextual Teaching And Learning At AdMathEdu | Vol.10 No.1| Juni 2020 The srovejuyu vruversuy rucrivung. International Journal of Education and Research. Vol. 2 No. 10

Djamarah, S. B., 2003. Psikologi Belajar. Jakarta :Rineka Cipta.

Dwiyana. 2015. Realistic Mathematics Learning Using Cooperative Model in Junior High School. (online). 
(www.iiste.org, Home, Vol. 6, No. 29 (2015)). Diakses 28Juli 2016.

Ekowati, K, Ch, Ardi M, Darwis, M, Puaupa, H, M, D, Tahmir, S, Dirawan, G,D, “The Application of Realistic Mathematics Education Approach In Theaching Mathematics In Penfui Kupang”, International Journal of Education and Information Studies ISSN 2277-3169 Volume 5 1(2015), pp. 35-43.

Haryati, S., 2017. Pendidikan Karakter dalam Kurikulum 2013. TersediaSecara Online Http : lib Untidar Ac IdwpContentuploadsDiaksesBdg. Indonesia. 17 Maret 2017.

Plomp. 2013. Educational Design Research. Enschede, Netherland: National Institute for Curriculum Development.

Rochmad, 2012. Desain Model Pengembangan Perangkat Pembelajaran Matematika hal 3.

Sadra, 2007. Pengembangan model pembelajaran matematika berwawasan lingkungan dalam pelatihan guru kelas I $S D$. Univ. Negeri Surabaya.

Suprijono, A., 2009. Teori Dan Aplikasi.

Tanjungsari, R. D., 2011. Diagnosis Kesulitan Belajar Matematika SMP Pada Materi Himpunan Pada Siswa Kelas VIII SMPN 2 Kertanegara Kabupaten Tahun Ajaran 2011/2012. Univ. Negeri Semarang.

Trianto, 2009. Mendesain model pembelajaran inovatif-progresif. Kencana Prenada Media Grup.

Widoyoko, S. Eko Putro. 2009. Evaluasi Program Pembelajaran hal 16. 
